\title{
ALTERNATIF PENGGUNAAN SERAT ECENG GONDOK UNTUK MENINGKATKAN INDEX PROPERTIES OF MARSHALL PADA CAMPURAN
} LASTON TIPE I SNI 03-1737-1989

\author{
Dwi Kartikasari ${ }^{1}$; Samsul Arif ${ }^{2}$ \\ ${ }^{1,2}$ Fakultas Teknik Universitas Islam Lamongan \\ email :dwiksaripsts@unisla.ac.id; samarifpsts.unisla.ac.id
}

\begin{abstract}
However, flexible pavement has many disadvantages, such as early damage to the road surface after some time has passed by traffic so the road cannot reach the planned age. For this reason, a research was carried out to add hot asphalt mixture which aims to improve the quality of the mixture, the selected material is natural water hyacinth. The method used is trial and error with reference SNI 03-1737-1989. Variations used were $3 \%, 5 \%$, and $7 \%$ of asphalt weight, the level of asphalt used was $4.48 \%$. Of the 3 variations of the mixture used in Type I Asphalt Concrete Layer, the results obtained that the water hyacinth fiber content that has the best score and meet the specifications of SNI 03-1737-1989 is the percentage of 7\% obtained. from the calculation data using graphs and regression models where Marshall Stability is $889.73 \mathrm{Kg}$, VFWA (voids filled with asphalt) are equal to 65.97\%, VIM (voids in mixtures) are equal to $1.757 \%$, VMA (voids in mineral aggregates) is equal to $20.30 \%$, density $2.420 \mathrm{gr} /$ cc, Flow $3.37 \mathrm{~mm}$, and Marshall Quotient of $265.80 \mathrm{Kg} / \mathrm{mm}$.
\end{abstract}

Keywords : flexible pavement, water hyacinth fiber, Marshall test.

\begin{abstract}
ABSTRAK
Namun, perkerasan lentur memiliki banyak kelemahan, seperti kerusakan awal pada permukaan jalan setelah beberapa waktu berlalu lalang sehingga jalan tidak dapat mencapai usia yang direncanakan. Untuk alasan ini, penelitian dilakukan untuk menambahkan campuran aspal panas yang bertujuan untuk meningkatkan kualitas campuran, bahan yang dipilih adalah eceng gondok air alami. Metode yang digunakan adalah coba-coba dengan referensi SNI 03-1737-1989. Variasi yang digunakan adalah 3\%, $5 \%$, dan 7\% dari berat aspal, tingkat aspal yang digunakan adalah 4,48\%. Dari 3 variasi campuran yang digunakan pada Tipe I Asphalt Concrete Layer, diperoleh hasil bahwa kandungan serat eceng gondok yang memiliki skor terbaik dan memenuhi spesifikasi SNI 03-1737-1989 adalah persentase 7\% yang diperoleh. dari data perhitungan menggunakan grafik dan model regresi di mana Marshall Stability adalah 889,73 Kg, VFWA (rongga diisi dengan aspal) sama dengan 65,97\%, VIM (rongga dalam campuran) sama dengan 1,757\%, VMA (rongga dalam agregat mineral) sama dengan hingga 20,30\%, kepadatan 2,420 gr / cc, Aliran 3,37 mm, dan Marshall Quotient dari 265,80 Kg / mm.
\end{abstract}

Kata Kunci: perkerasan lentur, serat eceng gondok, uji Marshall.

\section{PENDAHULUAN}

Indonesia sebagai negara berkembang, dengan keanekaragaman dan kekayaan alam yang dimiliki membuat teknologi di negeri ini berkembang sangat pesat terutama pada dunia transportasi, hal ini ditandai dengan semakin lancarnya arus transportasi darat. Ini membuktikan bahwa konstruksi jalan raya telah mengalami kemajuan dari masa ke masa. Kehandalan teknologi dan ilmu pengetahuan sangat di harapkan untuk menghadapi tantangan dalam 
peningkatan kuantitas dan kualitas jalan yang akan dibangun dan dalam masa pemeliharaan. Peningkatan jalan di Indonesia umumnya menggunakan aspal minyak sebagai bahan pengikat, namun masih banyak di jumpai kelemahan - kelemahan berupa kerusakan dini pada permukaan jalan setelah beberapa waktu di lalui oleh bermacam kendaraan sehingga jalan tersebut tidak mencapai umur rencana, maka dari itu dengan teknologi yang sudah ada akan dilakukan suatu penelitian dengan menambahkan serat selulosa yang di dapatkan dari eceng gondok sebagai bahan campuran pada laston. Fungsi serat selulosa sebagai bahan campuran aspal ini dapat menyerap aspal, memperkuat kekuatan ashesi dan dapat menstabilkan serta memperkuat aspal. Bahan tambah additive sebagai campuran aspal yang di gunakan biasanya serat selulosa contohnya road cell 50. Untuk mendapatkan bahan additive tersebut tidak mudah dan bahan tersebut mahal. Mengingat tanaman eceng gondok yang banyak dijumpai di daerah Lamongan serta minimnya pemanfaatan baik sebagai bahan kerajinan atau yang lainnya, untuk itu dalam penelitian ini mencoba memanfaatkan enceng gondok sebagai bahan campuran Lapis Aspal Beton ( Laston ). Penelitian ini dilakukan untuk mengetahui pengaruh penggunaan serat enceng gondok sebagai bahan pengganti serat selulosa pada campuran Laston Tipe I SNI 03 - 1737 1989.

\section{METODE PENELITIAN}

Penelitian yang telah dilakukan di Laboratorium Teknik Sipil Universitas Islam Lamongan ini menggunakan metode Trial and Error atau coba-coba untuk mendapatkan kadar terbaik pada campuran aspal panas pada Laston Tipe I SNI 03-1737-1989. 


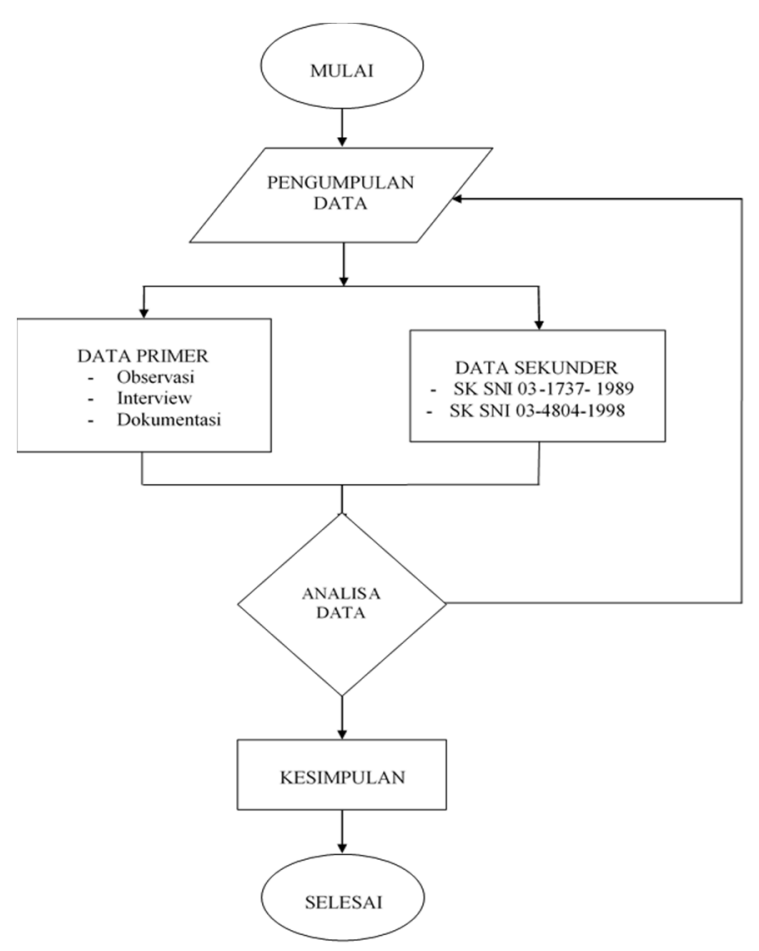

Gambar 1. Flowchart Alur Penelitian Sumber : Rancangan Penelitian, 2018

\section{HASIL DAN PEMBAHASAN}

\section{Pemeriksaan Agregat Kasar dan Halus}

Dalam penelitian ini agregat kasar yang digunakan yaitu batu pecah asal Mojokerto dan agregat halus pasir dari kali brantas.

Pada pengujian agregat kasar dan halus dilakukan dua pemeriksaan, diantaranya yaitu pemeriksaan berat jenis dan penyerapan seperti pada tabel 1 dan 2 berikut :

Tabel 1 Hasil Pemeriksa an Agregat Kasar

\begin{tabular}{lcc}
\cline { 3 - 3 } Jenis Pemeriksaan & Hasil & $\begin{array}{c}\text { Persyaratan } \\
\text { SN1 } 1 \text { yoy-LUU }\end{array}$ \\
\cline { 3 - 3 } Berat Jenis Bulk & $2,51 \mathrm{gr} / \mathrm{cc}$ & $\geq 2,5 \mathrm{gr} / \mathrm{cc}$ \\
Berat Jenis SSD & $2,55 \mathrm{gr} / \mathrm{cc}$ & $\geq 2,5 \mathrm{gr} / \mathrm{cc}$ \\
Berat Jenis semu & $2,62 \mathrm{gr} / \mathrm{cc}$ & $\geq 2,5 \mathrm{gr} / \mathrm{cc}$ \\
Penyerapan & $1,65 \%$ & $\leq 3 \%$ \\
Sumber : Hasil Penelition dan Perhitungan, 2018
\end{tabular}




\section{Tabel 2 Hasil Pemeriksa an Agregat Halus}

\begin{tabular}{lcc}
\cline { 2 - 3 } Jenis Pemeriksaan & Hasil & $\begin{array}{c}\text { Persyaratan } \\
\text { SN1 } 1 \text { yoy- } 200 \mathrm{~V}\end{array}$ \\
\cline { 3 - 3 } Berat Jenis Bulk & $2,56 \mathrm{gr} / \mathrm{cc}$ & $\geq 2,5 \mathrm{gr} / \mathrm{cc}$ \\
Berat Jenis SSD & $2,61 \mathrm{gr} / \mathrm{cc}$ & $\geq 2,5 \mathrm{gr} / \mathrm{cc}$ \\
Berat Jenis semu & $2,68 \mathrm{gr} / \mathrm{cc}$ & $\geq 2,5 \mathrm{gr} / \mathrm{cc}$ \\
Penyerapan & $1,79 \%$ & $\leq 3 \%$ \\
Sumber : Hasil Penelitian dan Perhitungan, 2018
\end{tabular}

\section{Pemeriksaan Aspal}

Pada pemeriksaan, aspal yang digunakan yaitu aspal dengan pen 60/70 yang didapatkan dari PT. Cahaya Indah Madya Pratama. Terdapat beberapa jenis pemeriksaan yang dilakukan, diantaranya Uji Penetrasi, Uji Titik Nyala dan Bakar, Uji Titik Lembek, serta Uji Berat Jenis Aspal seperti pada tabel berikut :

\begin{tabular}{|c|c|c|c|}
\hline $\begin{array}{c}\text { Jenis } \\
\text { Pemeriksaan }\end{array}$ & Hassil & Persyaratan & $\mathrm{SNI}_{\mathrm{N}}$ \\
\hline Penetrasi $25^{\circ} \mathrm{C}$, & $67 \mathrm{~mm}$ & $60-79 \mathrm{~mm}$ & $2456-2011$ \\
\hline $\begin{array}{l}\text { Titik Nyala } \\
\text { Titik Bakar } \\
\text { Titik Lembek } \\
\text { Berat Jenis } \\
\text { Aspal }\end{array}$ & $\begin{array}{c}329^{\circ} \mathrm{C} \\
334^{\circ} \mathrm{C} \\
49,5^{\circ} \mathrm{C} \\
1,02 \\
g r / c C\end{array}$ & $\begin{array}{c}\operatorname{Min} 200^{\circ} \mathrm{C} \\
\operatorname{Min} 300^{\circ} \mathrm{C} \\
48-58^{\circ} \mathrm{C} \\
\geq 1,00\end{array}$ & $\begin{array}{l}2433-2011 \\
2433-2011 \\
2434-2011 \\
2441-2011\end{array}$ \\
\hline
\end{tabular}

Sumber : Hasil Penelitian dan Perhitungan, 2018

\section{Perencanaan Campuran Kerja (Job Mix)}

Untuk memperoleh campuran bahan yang memenuhi spesifikasi diperlukan perencanaan campuran yang baik antar bahan penyusunnya. Perencanaan campuran ini dimaksudkan untuk menentukan proporsi penggunaan agregat kasar, agregat sedang, agregat halus dan pasir alami dalam campuran Laston Tipe XI SNI 03-1737-1989.

\section{Gradasi Agregat}

Setelah diperoleh komposisi campuran kemudian dilakukan penimbangan agregat sesuai dengan proporsi campuran Laston Tipe XI. Batasan gradasi agregat menurut spesifikasi Laston Tipe XI SNI 03-1737-1989 dapat dilihat pada grafik berikut : 


\begin{tabular}{ccc} 
saringan (inc) & saringan (mm) & medium \\
\hline $11 / 2 "$ & 38,1 & \\
\hline 1 & 25,4 & 100 \\
\hline $3 / 4 "$ & 19,1 & 92 \\
\hline $1 / 2 "$ & 12,7 & 0 \\
\hline $3 / 8 "$ & 9,52 & 87,5 \\
\hline No. 4 & 4,76 & 45 \\
\hline No. 8 & 2,38 & 27,5 \\
\hline No. 30 & 0,59 & 16 \\
\hline No. 50 & 0,279 & 11 \\
\hline No. 100 & 0,149 & 8 \\
\hline No. 200 & & 5 \\
\hline PAN & & 0 \\
\hline
\end{tabular}

Gambar 2. Grafik Batasan Gradasi Agregat

Stability Marshall

Sumber : Hasil Perhitungan, 2018

Dari hasil uji Marshall didapatkan data kenaikan serta penurunan nilai Stability Marshall yang dipengaruhi oleh penambahan serat eceng gondok. Penurunan nilai stabilitas yang terjadi dipengaruhi oleh volume antar agregat yang terlalu tinggi serta penguncian antar partikelnya yang kurang merata sehingga menyebabkan nilai stabilitas tidak mencapai standart spesifikasi yang telah ditentukan. Selanjutnya dibuat permodelan grafik untuk melihat kenaikan serta penurunan nilai stabilitas sebagai berikut :

Gambar 3. Grafik Hubungan Stability Marshal

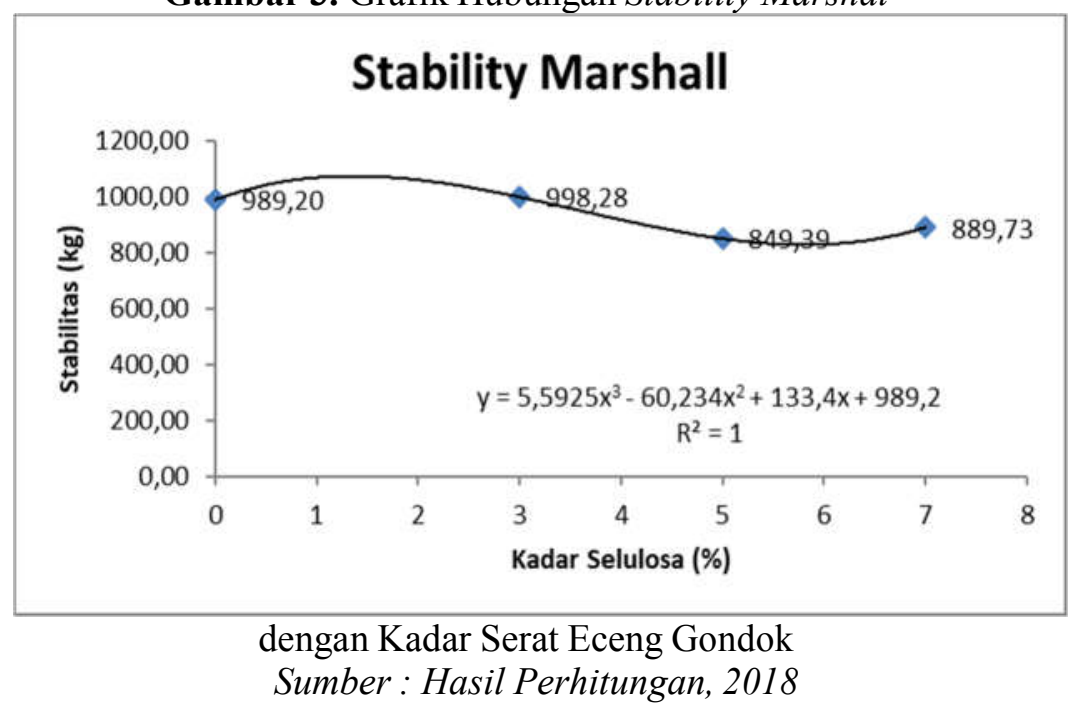

Dari grafik hubungan stability marshall dengan kadar serat eceng gondok diatas dapat dilihat dari penambahan kadar serat 3\%-7\% nilai stabilitas sudah mencapai nilai standart spesifikasi yang telah ditentukan yaitu $850 \mathrm{~kg}$ menurut spesifikasi Laston SNI 03-1737-1989. Tetapi nilai pada campuran kadar serat 7\% stability marshall sudah memenuhi standart 


\section{Voids Filled With Asphalt}

Penambahan serat eceng gondok juga mempengaruhi nilai VFWA (rongga terisi aspal) yang menyebabkan kenaikan serta penurunan yang disebabkan karena semakin banyak kadar serat selulosa eceng gondok yang digunakan, maka rongga yang ada dalam campuran akan menjadi besar dan campuran menjadi terpisah - pisah yang menyebabkan aspal tidak mengikat dengan baik. Selanjutnya dibuat permodelan grafik untuk melihat naik turunnya nilai VFWA sebagai berikut :

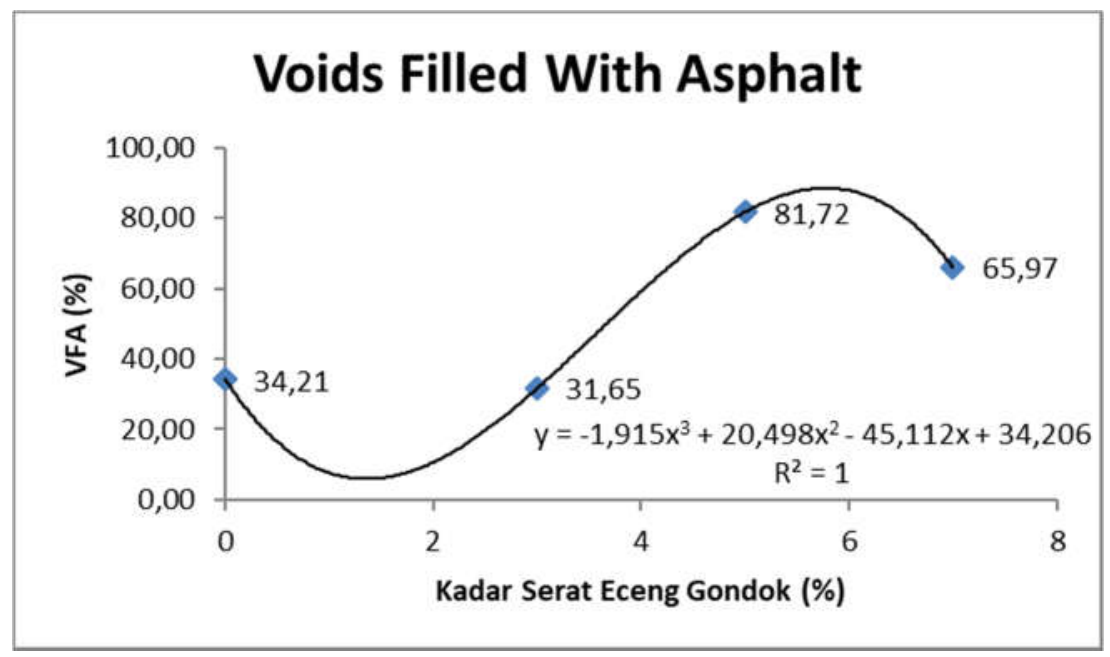

Gambar 4. Grafik Hubungan Voids Filled With Asphalt dengan Kadar Serat Eceng

Gondok Sumber : Hasil Perhitungan, 2018

\section{Voids In The Mix}

Pada pengujian Marshall Test, nilai VIM atau rongga dalam campuran mengalami kenaikan serta penurunan yang dipengaruhi oleh penambahan kadar serat eceng gondok yang terjadi karena meningkatnya kadar serat dalam campuran, karena semakin banyak kadar serat dalam campuran akan membuat campuran menjadi terpisah-pisah karena aspal terserap oleh seret eceng gondok sehingga daya ikat aspal menjadi berkurang dan menyebabkan rongga-rongga dalam campuran meningkat. Untuk melihat kenaikan dan penurunan nilai VIM dibuat grafik sebagai berikut :

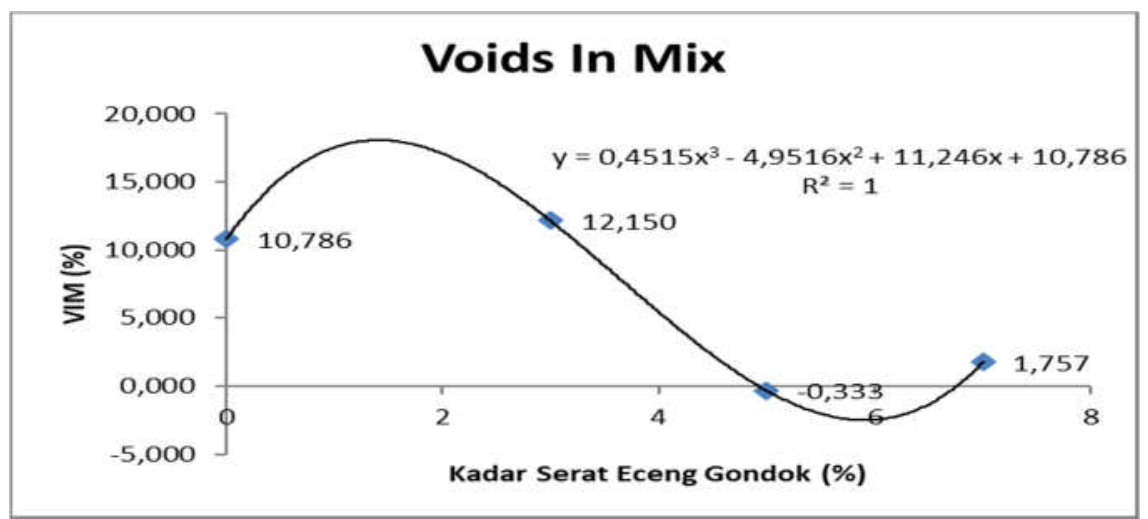


Gambar 5. Grafik Hubungan Voids In The Mix dengan Kadar Serat Eceng Gondok

Sumber : Hasil Perhitungan, 2018

\section{Voids In Mineral Agregate}

VMA adalah rongga antar butiran agregat dalam campuran aspal yang sudah dipadatkan. Pada pengujian Marshall Test penambahan serat eceng gondok membuat nilai VMA mengalami kenaikan dan beberapa ada penurunan karena semakin banyak kadar serat selulosa eceng gondok yang digunakan, rongga- rongga dalam agregat akan menjadi besar sebab aspal tidak mengikat agregat dengan baik. Berikut merupakan grafik hubungan Voids In Mineral Agregate dengan kadar serat eceng gondok :

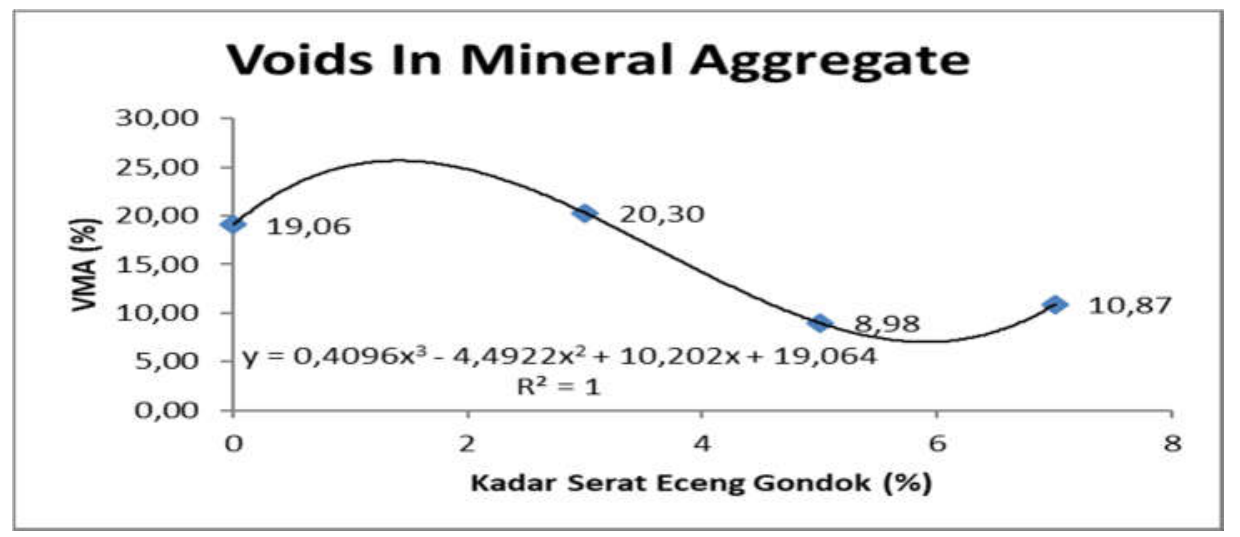

Gambar 6. Grafik Hubungan Voids In Mineral Agregate dengan Kadar Serat Eceng Gondok Sumber : Hasil Perhitungan, 2018

\section{Density}

Density atau kepadatan merupakan berat isi dari campuran yang menunjukkan tingkat Kerapatan suatu campuran yang telah dipadatkan. Pada pengujian Marshall Test, Penambahan serat eceng gondok berpengaruh terhadap density. Hal-hal yang mempengaruhi naik turunnya nilai density yaitu agregat yang digunakan sebagai bahan susun campuran tidak menyatu dengan sempurna dengan campuran aspal sehingga benda uji tidak terlalu padat dan pada proses penumbukan kurang maksimal. Selanjutnya dibuat permodelan grafik untuk melihat kenaikan dan penurunan nilai density sebagai berikut :

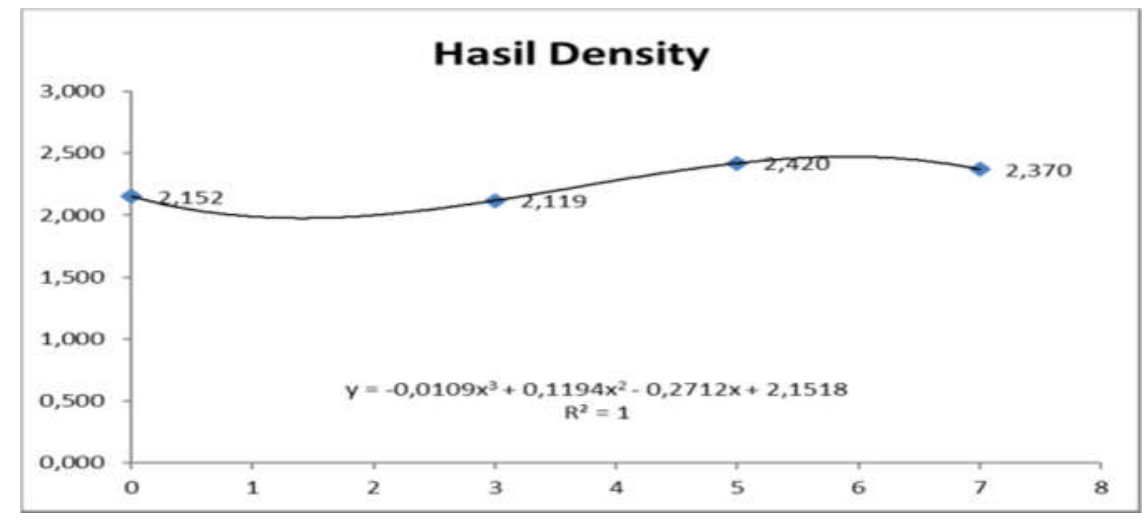


Gambar 7. Grafik Hubungan Density dengan Kadar Serat Eceng Gondok Sumber : Hasil Perhitungan, 2018

Flow

Penambahan kadar serat eceng gondok mempengaruhi hasil dari kelelehan plastis (flow). Faktor yang mempengaruhi kenaikan serta penurunan pada flow yaitu semakin banyak penambahan serat eceng gondok, maka semakin berkurang kadar aspal sehingga mengakibatkan perekatan agregat dan aspal tidak sempurna dan menyebabkan kegetasan. Selanjutnya dibuat permodelan grafik untuk melihat kenaikan dan penurunan nilai flow sebagai berikut:

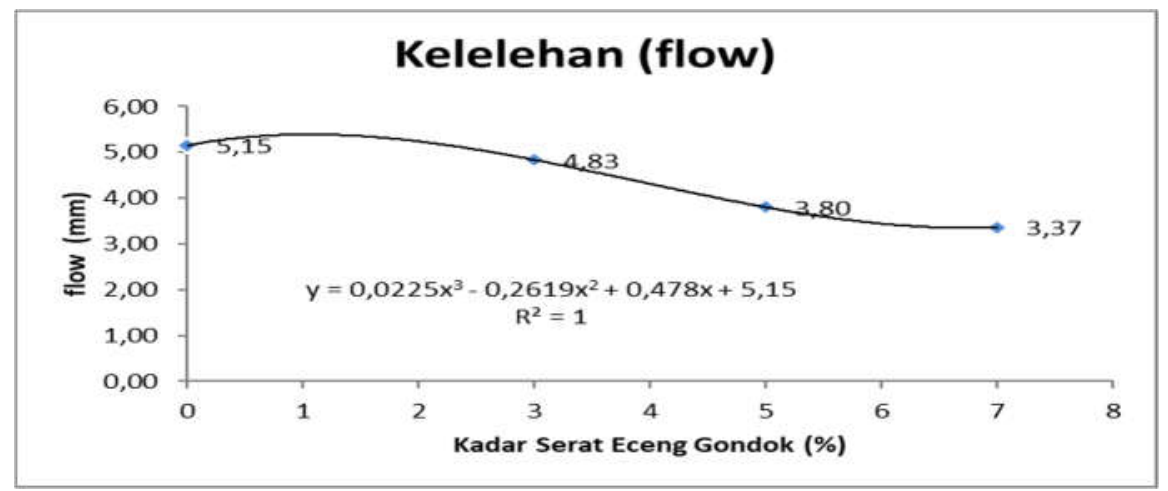

Gambar 8. Grafik Hubungan Flow dengan Kadar Serat Eceng Gondok

\section{Marshall Quotient}

Sumber : Hasil Perhitungan, 2018

Marshall Quotient adalah hasil nilai bagi dari nilai stability marshall dengan flow. Pada pengujian marshall test, penambahan serat eceng gondok mempengaruhi penurunan serta kenaikan nilai MQ yang terjadi karena campuran aspal terlalu banyak yang menyebabkan benda uji terlalu lentur, serta campuran bahan tambah dan aspal tidak mengikat secara sempura. Kenaikan serta penurunan nilai marshall quotient dapat dilihat pada grafik berikut :

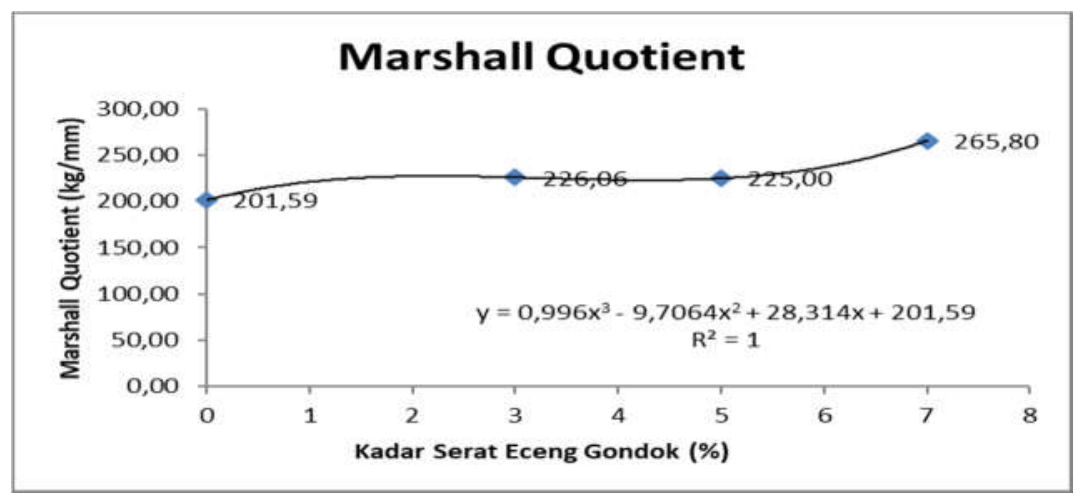

Gambar 9. Grafik Hubungan Marshall Quotient dengan Kadar Serat Eceng Gondok Sumber : Hasil Perhitungan, 2018

\section{KESIMPULAN}




\section{Kesimpulan}

Dari penelitian yang telah dilakukan mengenai penambahan serat eceng gondok Sebegai bahan alternatif admixture pada Laston tipe I SNI 03-1737-1989 dan ditijau terhadap nilai-nilai uji marshall didapatkan kesimpulan dari hasil penelitian sebagai berikut:

1. Berdasarkan penelitian yang telah dilakukan, serat eceng gondok dapat digunakan sebagai bahan pengganti serat selulosa dan dapat digunakan sebagai bahan campuran aspal panas karena serat eceng gondok mampu menyerap aspal serta memperkuat aspal.

2. Dalam pembuatan serat econg gondok yang digunakan dalam penelitian ini dilakukan pengolahan dengan cara menghaluskan atau menggiling eceng gondok yang sudah di potong dan dibersihkan sampai mendapatkan karakteristik yang menyerupai serat selulosa yang sesungguhanya. Serat Eceng gondok sendiri dimaksdukan sebagai tambahan tambah yang dapat mengurangi banyaknya aspal yang digunakan dalam campuran.

3. Penambahan serat eceng gondok terhadap nilai-nilai Marshall Properties beberapa mengalami peningkatan.

Dalam penambahan serat eceng gondok sendiri mempengaruhi hasil dari Marshall Test yang mengalami kenaikan serta penurunan. Dari 3 variasi campuran yang digunakan pada campuran Laston tipe I didapatkan kadar serat eceng gondok yang nilainya terbaik dan memenuhi spesifikasi SNI 03-1737-1989 adalah kadar serat 7\% yang di dapat dari data perhitungan menggunakan grafik serta perhitungan permodelan regresi, dimana Marshall Stability yang di dapatkan yaitu 889,73 Kg, VFWA (void diisi dengan aspal) adalah sama hingga $65,97 \%$, VIM (void dalam campuran) adalah sama dengan 1,757\%, VMA (void dalam agregat mineral) adalah sama dengan 20,30\%, densitas 2,420 gr / cc, Kelelehan 3,37 mm, dan Marshall Quotient dari 265,80 Kg / mm.

\section{Saran}

Adapun beberapa saran dari penulis untuk penelitian selanjutnya agar dapat lebih baikdikemudian hari yaitu :

1. Dalam tahap pengolahan eceng gondok, sebaiknya digunakan alat khusus untuk menghaluskan atau menggiling serat agar didapatkannya karakteristik yang baik dan menyerupai serat selulosa yang sesungguhanya

2. Sebaiknya pada saat penelitian lebih banyak menggunakan variasi serat eceng gondok sebagai bahan perbandingan untuk mendapatkan kadar serat yang paling baik digunakan untuk bahan campuran aspal panas

3. Pada saat proses pemasakan atau pencampuran agregat dengan aspal kondisi suhu aspal saat dipanaskan harus lebih diperhatikan karena aspal yang tidak mencapai suhu 
optimal akan menjadi kental dan akan berpengaruh pada kondisi aspal saat ditumbuk

4. Dalam proses penimbangan bahan sebaiknya menggunakan alat timbang yang memiliki sistem digital agar dalam penimbangan bahan didapatkan hasil yang lebih akurat

5. Kondisi alat dalam pengujian sebaiknya menggunakan alat yang kondisinya baik, agar didapatkan hasil yang akurat.

\section{REFERENSI}

[1] Rizkianto, T., Setyawan, A., \& Sarwono, D. (2015). PENGARUH PENGISIAN RONGGA PADA CAMPURAN ASPAL PORUS MENGGUNAKAN ASPAL POLIMER STARBIT E-55 TERHADAP KUAT TEKAN DAN KUAT TARIK. Matriks Teknik Sipil, 3(2).

[2] Kumalawati, A., Sir, T. M., \& Mastaram, Y. (2013). Analisis Pengaruh Penggunaan Abu Batu Apung Sebagai Pengganti Filler Untuk Campuran Aspal. Jurnal Teknik Sipil, 2(2), 191-200.

[3] Gani, D. R. (2013). Pengaruh Penggunaan Bahan Tambah Berbasis Hydrocarbon Terhadap Karakteristik Aspal Porus.

[4] Muaya, G. S., Kaseke, O. H., \& Manoppo, M. R. (2015). Pengaruh Terendamnya Perkerasan Aspal oleh Air Laut yang Ditinjau terhadap Karakteristik Marshall. Jurnal Sipil Statik, 3(8).

[5] Edison, B. (2014). Karakteristik Campuran Aspal Panas (Asphalt Concrete-Binder Course) Menggunakan Aspal Polimer. Jurnal Aptek, 2(1), 60-71.

[6] SNI (1989). Tata Cara Pelaksanaan Lapis Aspal Beton (Laston) Untuk Jalan Raya. SNI 03-1737-1989.

[7] SNI (2008). Cara Uji Berat Jenis Dan Penyerapan Agregat Halus. SNI 1970 : 2008.

[8] SNI (2011). Cara Uji Berat Jenis Aspal. SK SNI 2441-2011.

[9] SNI (2011). Cara Uji Penetrasi Aspal. SK SNI 2456-2011.

[10] SNI (2011). Pengujian Titik Lembek Aspal. SK SNI 2434-2011.

[11] SNI (2011). Pengujian Titik Nyala dan Titik Bakar Aspal. SK SNI 2433-2011.

[12] AASHTO. 1990. Standard Specifications For Transportation Materials And Methods of Sampling and Testing. Part II. "Tests". Fifteenth Edition. Washington,D.C.

[13] ASTM D 1559-76 atau AASHTO T-245-90, Rancangan Campuran Berdasarkan Metode Marshall.

[14] April Gunarto, A. I. C. K. (2019). Penelitian Campuran Aspal Beton Dengan Menggunakan Filler Bunga Pinus. UKaRsT, 3(1), 37. https://doi.org/10.30737/ukarst.v3i1.351

[15] Candra, A. I., Mudjanarko, S. W., \& Limantara, A. D. (2017). Manajemen Data Lalu Lintas Kendaraan Berbasis Sistem Internet Cerdas Kadiri. Semnastek, 4(2), 1-2. Retrieved from jurnal.umj.ac.id/index.php/semnastek

[16] Departemen Pekerjaan Umum. 1987. Petunjuk Pelaksanaan Lapis Aspal Beton (Laston) Untuk Jalan Raya.

[17] Departemen Pekerjaan Umum. 1999. Pedoman Perencanaan Campuran Beraspal Panas Dengan Pendekatan Kepadatan Mutlak Jakarta: PT. Mediatama Saptakarya (PT. Medisa). 